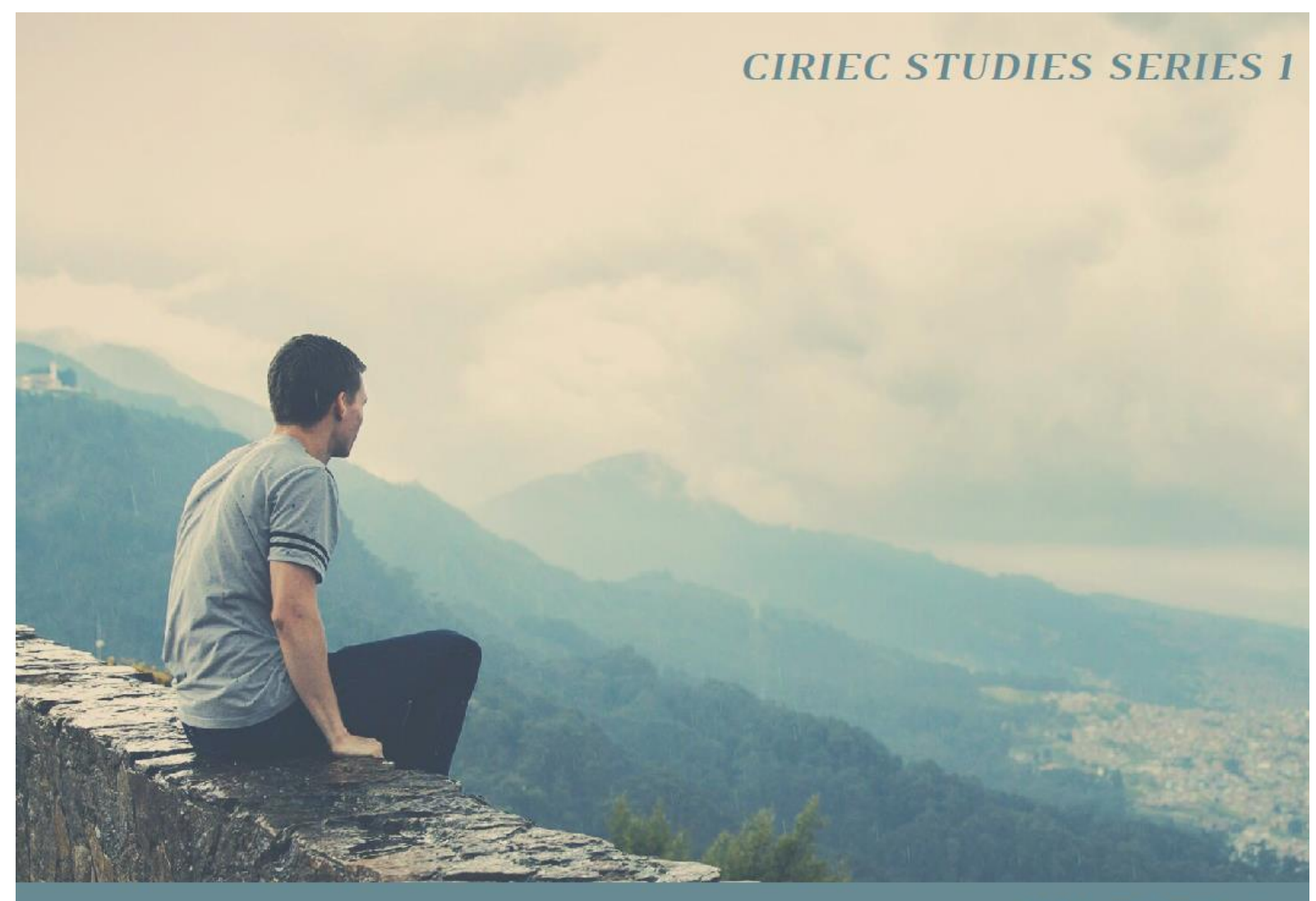

CHAPTER 11

THE INSTITUTIONAL ORGANIZATION OF HEALTH IN COLOMBIA AND ITS DISCONNECTION WITH THE COMMON GOOD AND MUTUALITY

Juan Fernando Álvarez Miguel Gordo Granados Hernando Zabala Salazar

Part of Providing public goods and commons. Towards coproduction and new forms of governance for a revival of public action by Philippe BANCE (dir.), 2018 


\section{CIRIEC (International Centre of Research and Information on the Public, Social and Cooperative Economy) is a non-governmental international scientific organization.}

Its objectives are to undertake and promote the collection of information, scientific research, and the publication of works on economic sectors and activities oriented towards the service of the general and collective interest: action by the State and the local and regional public authorities in economic fields (economic policy, regulation); public utilities; public and mixed enterprises at the national, regional and local levels; the so-called "social economy" (not-for-profit economy, cooperatives, mutuals, and non-profit organizations); etc.

In these fields CIRIEC seeks to offer information and opportunities for mutual enrichment to practitioners and academics and to promote international reflection and action

CIRIEC activities, publications and researches are realized with the support of
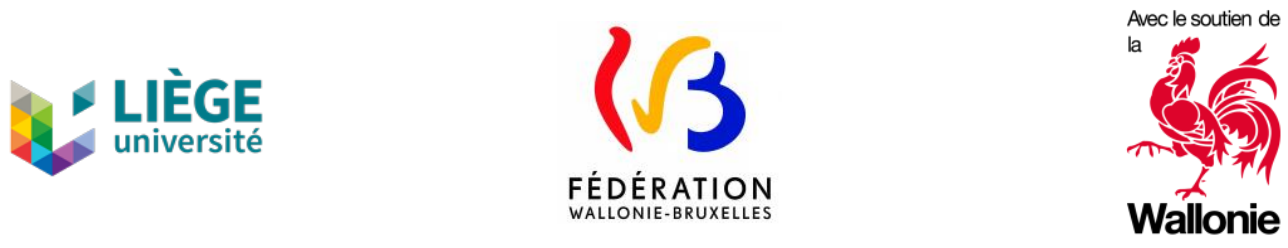

This publication has been peer-reviewed.

No part of this book may be reproduced in any form, by print, photocopy, microfilm or any other means, without prior written permission from the publisher. All rights reserved.

(C) CIRIEC aisbl, 2018

Université de Liège

Quartier Agora

Place des Orateurs, 1

Bât. B33, bte 6, BE-4000 Liège

ciriec@uliege.be; http://www.ciriec.uliege.be

ÁLVAREZ, Juan Fernando, GORDO GRANADOS, Miguel and ZABALA SALAZAR, Hernando.

"The institutional organization of health in Colombia and its disconnection with the common good

and mutuality / Chapter 11". In: CIRIEC and BANCE, Philippe (dir.). Providing public goods and commons.

Towards coproduction and new forms of governance for a revival of public action. Liège: CIRIEC, 2018.

(CIRIEC Studies Series; 1), pp. 231-248.

http://doi.org/10.25518/ciriec.css1chap11

This publication is indexed and available in $\underline{\operatorname{RePEC}}$ 


\title{
The institutional organization of health in Colombia and its disconnection with the common good and mutuality / Chapter 11
}

\author{
Juan Fernando ÁLVAREZ ${ }^{*}$, Miguel GORDO GRANADOS ${ }^{* *}$, \\ Hernando ZABALA SALAZAR ${ }^{* *}$
}

\begin{abstract}
This chapter analyzes the provision of health services in Colombia, which are constitutionally recognized even if in reality they are far from being guaranteed in terms of gratuity and universal coverage for most of the population. A situation possibly brought about by the market orientation promoted by the legal framework and the effects it has brought in terms of general interest, in exclusion and in the tendency towards the deterioration in the provision of services. Some of the actors in the system, characterized by a common property, offer a real and effective alternative in getting closer to the right to health for all.

In this context, the organizational logic of mutual associations stands out as an instrument to optimize public health policy even if a new institutional dynamic is required, with anew relation between the State and social organizations. A relation in which the concept of common good is an appropriate starting point and finality as a strategy of governing the institutional agreements that improve the relations between the public organisms and the citizens.
\end{abstract}

Keywords: Colombian, health system, competition, optimization, common good, mutual JEL-Codes: P13, P36, P46, I11, I18

\footnotetext{
* Doctor in social sciences. Member of the research group UNES of the Institute of Rural Studies of the Pontificia Universidad Javeriana; Member of the Board of Directors of CIRIEC-Colombia (alvarez juan@javeriana.edu.co).

Master in economics. Expert in health and taxation of the Capital District. Member of CIRIEC-Colombia (miguelgord@gmail.com).

Specialist in cooperative law. Member of the ECOSOL group of Luis Ámigo University. President of the Board of Directors of CIRIEC-Colombia (hernando.zabalasa@amigo.edu.co).
} 


\section{Introduction}

In the case of the Colombian health system, the scheme adopted for the provision of services is that of regulated competition, in which operate health promotion entities, hereinafter HPE, public and private, as well as public and private providers. Within this framework, public hospitals, considered as state social enterprises, are responsible for providing health services to the lower income population.

The system of regulated competition sought to break with the welfare vision of offering universal services without control to the population affiliated or not to the subsidized regime. This generated that many people with capacity to pay their access to the health system did not do it in a context of a large shortage of public resources. In addition, this system inherited some patronage and corruption practices which makes the public hospitals fragile to face a competitive market, where the search for profitability rather than guaranteeing the right to health exposes them to budget shortages and to the growth of their liabilities to meet their commitments of spending with their workers, and suppliers of medicines and supplies.

In this context, there is a need to re-signify processes and goals and make the management of the public thing a process that responds to the needs of the community expressed in the common good.

In a recent investigation of the implementation of the GDP (Álvarez, 2016), 923 public entities were consulted in 2011 on the reporting of various topics contained in the Anti-Corruption Statute: publication of goods and services, corruption risk map, measures to mitigate risks, anti-procedural strategies, mechanisms to improve citizen's attention, website space for complaints and complaints, action plan with objectives, strategies, projects, goals, purchase plans, investment projects, budget disaggregation and indicators of management. The answers to this inquiry reveal the absence of supports that demonstrate efficiency in administration.

In those cases where a failure to comply with the regulations was reported, the preponderant arguments raise the lack of technical capacities for compliance, budgetary absences for the achievement of reporting means such as computer equipment and Internet access, and widespread confusion due to the lack of knowledge of which instruments should deal with the extensive requests for reporting systems required from the central government. To this must be added the persistence of gaps in the compliance report between centralized and decentralized agencies.

This allows us to measure the magnitude of the problem of the public thing in a context where citizens demand answers to collective needs and in which there is a dangerous paradox: while public bodies advocate increasing efficiency rates from the technical upgrading of higher goals, they are not able to solve the growing problems 
that cause inequality, exclusion and poverty and on the contrary, there is an increasing move away from the preservation of the common good.

In the case of public hospitals, some studies have evaluated their efficiency on the basis of methodologies such as the data envelopment analysis, the relations of equivalence, and the stochastic frontiers. The results are consistent in that the efficiency of these organizations increases with the level of complexity of services. Low-complexity hospitals, which are the majority in Colombia, are less efficient, but many times low efficiency is associated with the lack of transparency in the management of financial and human resources.

For example, in some cases, the investments in technology were done in computers that have not necessarily the function of ensuring the provision of a better medical service. Similarly, certain jobs in the hospitals respond to bureaucratic quotas and do not correspond to the best qualified human resource, mainly giving rise to a high turnover of administrative staff.

In the following sections we will delve into the institutional framework of the Colombian health system and the contradictions which arise between the constitutional considerations and practices that further reveal the disconnection with the common good.

\section{The role of general interest in defining the public thing}

Article 1 of the Political Constitution of Colombia reads:

Colombia is a social state under the rule of law, organized in the form of a unitary republic, decentralized, with autonomy of its territorial units, democratic, participatory and pluralistic, based on the respect for human dignity, the work and solidarity of individuals who belong to it and the prevalence of the general interest.

However, the concept in question is diffuse when applied. Based on some concepts of the Constitutional Court, made mostly in the 1990s, sentences without conceptual uniqueness were developed which, on the one hand, advocate the general interest as a blurred principle and, on the other hand, state it as a vital principle in the definition of public action, finally transferring the responsibility to each judge with attention to each particular context.

Sentence C-546 of 1992 states:

"The person is an end in itself" therefore: "Social progress cannot be built on the basis of individual prejudice, whether it is a minority or even a person." In this way the protection that should be given to fundamental rights cannot be "subject to the swing of the general interest"

For its part, Judgment No. T-428/92 states:

\footnotetext{
"In case of conflict between the general interest and another constitutionally protected interest the solution must be to find according to the legal elements that provide the concrete case and in the light of constitutional principles and values. This work of interpretation is a primary function of the judge and especially of the constitutional court "...
} 

Jean Rivero:

\begin{abstract}
As a social being, man cannot suffice himself: the free play of private initiatives allows him to attend to some of his needs, thanks to the division of labor and exchanges; but there are others, of the most essential, that cannot receive satisfaction in this way, or because being common to all members of the community, they exceed by far the possibilities of any particular - such as the need for national security, either because their satisfaction does not allow, by their nature, to make a profit, so that no one will offer to insure it. These needs, to which the private initiative cannot respond, and which are vital for the entire community and for each of its members, constitute the proper domain of the administration: it is the sphere of public interest (...)
\end{abstract}

It represents a set of human needs-those to which the game of liberties does not adequately serve, and whose satisfaction conditions nevertheless the fulfillment of individual destinies.

The motor of administrative action, on the other hand, is essentially disinterested: it is the pursuit of the general interest, or of public utility, or in a more philosophical perspective, of the common good...

At the same time, it tends to confuse the pursuit for the common good with the interest derived from the average voters; without expressing the pursuit for a supreme good fruit of social cooperation.

In 2001, the Constitutional Court, through Judgment C-053/01:

It is precisely the abstract and undetermined character of the public interest concept, that leaded liberal modern constitutions to consider the necessity in harmonizing it with individual rights and with the social value inherent to cultural diversity.

Thus the common good remains invisible under the ornament of the general interest and this in turn is tinged with ambivalences that allow each entity to define the orientations in an instrumental way.

From the Aristotelian tradition, the common good was incorporated by the Catholic Church through the works of Thomas Aquino to the doctrine of government of the public thing and consequently was assumed by the Western State structure in most of the Constitutions.

In practice, the common good has been understood as a condition for the exercise of life in society by individuals, families and organizations. However, this concept has been the standard bearer of multiple demands from citizenship expressed in associations in a context of marked systemic crisis. In this respect Argandoña $(2015$, p. 17) contextualizes its current meaning in the following events:

...Is still in force a generalized sense of insecurity, a mixture of fear and hopelessness towards the future, the awareness that partisan political discourse is exhausted, and the deepest awareness of the difficulty we find in create a framework of ideas and beliefs that allows to identify the good, practice justice, seek the truth and live in freedom and security.

However, this is permeated by a growing philosophical individualism that is the fruit of a society constituted as the aggregate of interests that are not always coincident. For this reason, speaking of the common good as a citizen aggregate can be an entelechy insofar as the citizen does not act in pursuit of the general interest, but in pursuit of his individual interest. In the midst of such a dilemma, the State and its 
organs of power appear as a socially efficient computer, despite the growing evidence of its incapacity.

Argandoña says (2015, p. 17):

Citizens don't need to be honored: an "invisible hand" will achieve stability and sustainability of society, thanks to democratic, state-directed and democratic procedures, which are conceived as a benevolent and wise arbiter capable of achieving harmony in that society of individuals who only cooperate according to their personal interests.

This situation places the State and public organs in the unattainable task of articulating the disconnection of citizen preferences and the common good ends up in overlapping in procedures to avoid discontent in the short term (Argandoña, 2015). Thus the institutions of yesteryear end up in bypassing their action with unrelated control measures in which the general interest of some is negotiated, for the general loss of others.

Proposals for regularization based on the common good (proposed by common good theorists) refer to legal persons in their relationship with the community, so the search for entities (and organizations) serves as a means to provide the greatest contribution to the welfare.

Thus, the common good represents a precept that advocates the improvement of conditions for the reproduction of life, in cooperation and reciprocity, aspects closely linked to the management of associative organizations where individuals not only seek to satisfy their interests, but which also manage to understand that it is not possible to seek individual interest if previously the agreements are not generated to act in articulation for the common benefit. Thus, the spirit, values and objectives of our Constitutions would achieve their implementation in the economy in a consistent way as explicitly stated by Felber (2013, p. 18).

The result would tend to harmonize the State's action with specific common goods reflected in the existence of transfers of competences, responsibilities and mechanisms for the organized community to participate in the evaluation of public activities. This will imply the State's obligation to provide material and immaterial conditions to all its centralized and decentralized agencies to facilitate participation and control.

\section{The General System of Social Security in Health}

In Colombia, the Constitution of 1991, Article 48, established that social security is a mandatory public service and through Law 100 of 1993, the current Social Security System was institutionalized, which includes the obligations of the State and the society to provide the institutions and the resources in order to guarantee the coverage of the health services and those that are complementary. It is pointed out that the State is in charge of the direction, coordination and control of this service 
under principles of efficiency, universality and solidarity, and the health services should be organized in a decentralized manner and by levels of attention.

The Political Constitution also establishes a basic principle of gratuitous and obligatory character for all the people, along with the access that they have to the public service of health and of environmental sanitation. However it is to be emphasized that strictly health is not contemplated in the chapter of Fundamental Rights, but is part of social, economic and cultural rights. In compliance with the constitutional order, the State enforces the right to health of its habitants through the General System of Social Security in Health.

According to Law 100 of 1993, the Integral Social Security System in Colombia consists of the pension, health and occupational risk systems, and complementary social services. The provision of services is done through an insurance scheme ${ }^{1}$ of two regimes: the subsidized regime for the poor without payment capacity; and secondly, the contributory scheme, for employees, self-employed and persons with ability to pay. A separate group includes the poor non-affiliated population that receives the health services in consideration of the constitutional order that establishes health as a public service to which the entire population has the right.

Those affiliated to the contributory scheme through the health promotion entities (HPE) ${ }^{2}$ are persons with a formal job (through some form of employment contract) or persons who work as independents. Individuals with payment capacity also belong to this scheme (employers, public servants, and pensioners, among others). The members of this regime receive a package of health care services called the obligatory health plan (OHP) which must be guaranteed by the affiliated HPE through the health care institutions $(\mathrm{HCl})$. The Plan includes actions for disease prevention and recovery of health, ranging from basic preventive medicine to various specialized treatments.

To receive health services, members of the contributory regime must make a monthly contribution of $12.5 \%$ of their base contribution income, of which $8.5 \%$ is paid by the employer and $4 \%$ by the worker. Independent workers fully assume the contribution, which is calculated on $40 \%$ of the value of the contract. These resources are the source of funding for the OHP, disability attention, maternity leave, promotion and prevention programs and also help to finance the subsidized regime.

The contributions are collected by the HPE and transferred to the Solidarity and Guarantee Fund (FOSYGA) which manages the resources of the Social Security System in Health, including those originated in the contributory scheme. These funds are transferred to the Compensation sub-account of FOSYGA after deducting the value of the Capitation Payment Unit (CPU), which corresponds to the value that the system recognizes to each HPE to guarantee the provision of the services of Health.

\footnotetext{
${ }^{1}$ The Ministry of Social Welfare, Social Health Security System 2006.

${ }^{2}$ HPE can be private, public or mixed.
} 
The subsidized health regime is aimed at the poorest population and those with special characteristics such as the indigenous, the displaced, among others, located in rural and urban areas, who receive a package of services similar to those of the contributory regime (OHP), but which are quoted below the value that they must pay if they were in this scheme, due to limited payment capacity of these population groups.

The subsidies granted for this regime come from national, departmental and municipal resources. Much of the resources of the subsidized regime are managed through the mechanism defined in article 31 of Law 1438 of 2011 and operated in the FOSYGA. Resources are settled according to the affiliated population in the name of the territorial entities, which is turned directly to the $\mathrm{HPE}$ and the $\mathrm{HCl}$.

In this scheme, it is the responsibility of the territorial entity to identify the poor and vulnerable population and to select the beneficiaries of the subsidized regime, using the Benefit Identification System (SISBEN), which, through a survey, classifies the potential beneficiaries in 6 levels. People classified in levels 1,2 and 3 are potential beneficiaries of the subsidies granted by different social sector entities including health subsidy.

Persons classified in SISBEN levels 1 and 2 and not affiliated to the contributory regime have the right to be insured, to receive the full health subsidy and have access to the Obligatory Plan of the Subsidized Regime (OHP-S). Likewise, people who are part of special groups such as: demobilized, indigenous, street dwellers, children in protection and displaced, can join this regime.

For those people with an economic situation that do not allow them to be classified in any of these modalities (with no ability to pay or not poor enough to be subsidized), the law provides for a transition regime with access to partial subsidies. This group includes the poor people who have not yet classified SISBEN, the special population not affiliated to the subsidized regime and, finally, the population classified in levels 1,2 and 3 of SISBEN that are not yet affiliated.

The registered population has the right to receive services to promote and prevent disease, diagnosis, treatment and rehabilitation of the disease in its different levels of complexity, supply of medicines, initial attention in the emergency service, anywhere in the country.

\section{Tensions in the postulates of the General System of Social Security in Health}

Law 100 of 1993 was influenced by multilateral organizations such as the World Bank which argued that the regulation and institutional development of an insurance policy would stimulate private capital investment, reduce public spending and promote competition between insurers and providers of services, improving the efficiency and quality of these services (World Bank, 2003). Therefore, existing social 
security institutions would have to modify their management model to enter into the logic of market competition, and the public service network should be decentralized to have independence and take advantage of market incentives in resource allocation to compete with private providers of these services (World Bank, 2003).

In the same Law, Article 202 establishes that in order to have access to the provision of the health service in the contributory regime, a sustained linkage must be made in the payment of a quotation. So in practice the service does not fulfill the two conditions of a pure public good: not feasible nor desirable to ration its use.

In summary, although health is considered a public service guaranteed by the State, it is supplied under the scheme of regulated competition, which means that it assumes the characteristics of a private good since the payment of the contribution excludes those individuals with limited capacity of payment that cannot be affiliated to the contributory system and the same good cannot be consumed simultaneously by two individuals.

Theoretically the literature is full of cases where the privatization of public activities generates disproportionate budgets: markets for exchange of pollution quotas, tolls for extraction, cooptation of supervisors, contracting circles among others running parallel to "technical efficiency".

Taking into account that in a regulated market the relevant variable is the ability to pay, and considering that health is not really a pure public good since it does not meet the double condition of non-rivalry and non-exclusion, how to reconcile a fundamental right such as health, with the benefit of health services through a complex network of public and private providers?

The permanent search to reconcile such situations triggers financial tensions in the system, which end up being covered by the State. Exclusion and rivalry apply to some groups of users, raising access barriers, which are not sufficient to restrict the overuse of services by other groups of users.

This is reflected in the perception that the health system has structural flaws that question its sustainability. The recent intervention and subsequent liquidation of the cooperative health promoter entity Saludcoop has been one of the most recent scandals of bad management practices, surcharges, patronage and others that have affected the image of the provision of health services in Colombia.

The results show that the postulates formulated by the multilateral organisms that promoted the model were not true and the efficiency of the institutional gear created was not fulfilled: hospitals modified their management model but that did not make them sufficiently competitive. Public entities are more independent from local governments, but still in the hands of politicians and networks of corruption, meanwhile the expenditure of the system has continued growing. The search for reconciling such a contradictory model has stressed the public debate about universal 
access. It focused the discussion on the results and not on the general interest dimension of health and on the necessary verification of the generation of common good that the operating companies must supply by the nature of the service they provide.

Law 1751 of 2015 was recently issued, known as the Statutory Health Law, which recognizes full rights to all Colombians. It states that the health service has the character of a fundamental social right and its principles emphasize the universality and the equity of the right, as well as a policy aimed at eliminating the "social determinants of health that affect the effective enjoyment of the right to health, promote health improvement, prevent disease and raise the quality of life." It adopts a collective approach to health promotion and prevention actions for all people (Article 2), as well as the State's obligations (Article 5). The State must adopt "policies that promote health promotion, prevention and care of the disease and rehabilitation of its sequelae, through collective and individual actions" (article 5, lit. c).

The implementation of this new law will take several years given the short-term impossibility of changing the current system and will substantially increase the financial pressures on the health system, forcing many promoters and providers to leave the system.

\section{Stylized facts: the vicissitudes of regulated competition}

The analysis developed shows that as of Law 100 of 1993, the Ministry of Health leaves the provision of services as direct provider and creates intermediary entities responsible for offering a compulsory health package by way of insurance contracting with the health provider institutions for the provision of services.

The proposed scheme was based on the approach of regulated competition (Enthoven, 1993). On the one hand, between health promotion entities (HPE) and health care institutions $(\mathrm{HCl})$, where health providers would act according to the amount demanded, insurers would have incentives to contract with those most attractive to the plaintiffs, and they would buy the product or plan benefits for a minimum of one year and according to the results. Users of the services could choose the best alternative to provide the plan. The model would be compatible with copayments and deductibles for specific services that would influence users to rationalize resource use.

Theoretically, in this scheme, the HPE are responsible for buying the health services for the user, among a set of providers. The $\mathrm{HCl}$, on the other hand, compete with each other to obtain the contracts with the HPE and as these receive a fixed amount for each affiliated person (CPU), they try to reduce the costs by contracting with suppliers $(\mathrm{HCl})$, that offer the lowest price, leaving in the background the quality of the services provided. The system allows $\mathrm{HPE}$ to have their own $\mathrm{HCl}$, and they can contract with them primarily, although Law 1122 of 2007 established limits to this 
vertical integration. The law orders HPE not to contract more than $30 \%$ of their health spending with their own $\mathrm{HCl}$, the remaining $70 \%$ being contracted with public or private $\mathrm{HCl}$.

The regulatory function was assumed by the State, initially through the Social Security Council in Health (CNSSS), which remained in the period 1994-2007, and later by the Health Regulatory Commission (CRES), whose objective was to guarantee the functioning of the market, with mechanisms such as: the insurance function in private hands, the standardized product design of the system, called the obligatory health plan (OHP) and the determination of the price of said annual plan, known as the capitation payment unit (CPU). The design included the rules for suppliers, health providers, intermediaries and consumers to fit the model.

In addition, an information system was implemented with the purpose of prioritizing the attention to the low-income population, known as the Beneficiary Selection System (SISBEN).

However, demand pressure was concentrated on suppliers to reduce costs, although market-based competition reforms work only if all those who can contribute to the system financing do so. Indeed such a system would not work if all are covered but only some pay, which is nothing other than the presence of "opportunists" and model distortion.

In this perspective, the system is in a situation of permanent financial tensions, which force the national government to formulate rescue strategies for the HPE, to intervene in public hospitals and eventually to close private hospitals because they are not economically viable.

Several hypotheses have been launched to explain the financial crisis of the health system. The Ministry of Health and Social Protection argued that the crisis is due to a situation that cannot be hidden: "The system has spent more than it has and continues to spend more than it has. He has not regained his balance "Although this is an authoritative voice on the subject, there is still a greater explanation on the subject".

According to statistics compiled by the World Bank on health expenditure by country (Graph 1), Colombia spends $7.2 \%$ of GDP in its health system in 2015 , very similar to the rest of Latin America, higher than that of the high middle-income countries (6.1\% of GDP) and those affected by situations of internal conflict $(5.6 \%$ of GDP). It should be noted that in a period of three years, between 1996 and 1999, health expenditure reached historical levels of $9 \%$ of GDP, then fell below $6 \%$ and since 2004 has shown an upward trend.

\footnotetext{
${ }^{3}$ Interview with Alejandro Gaviria, Minister of Health, in the Caracol chain, on October 12, 2016.
} 
The greater availability of financial resources has allowed to extend the coverage of the system. From a coverage of $33 \%$ at the beginning of the $1990 \mathrm{~s}^{4}$, coverage reached $97 \%$ in 2015 .

However, despite the increase in insurance coverage, access to health services, measured as the percentage of people who used medical services when needed, decreased during the period 1997-2012, according to a study carried out by the Bank of the Republic 5 .

This fact indicates problems of efficiency in the management of organizations that are part of the health system, because although there is more population covered by the system, access to services has been restricted. In an advanced study for a sample of 336 hospitals during the period 2003-2011, it was found that there was a drop in the productivity of Colombian public hospitals, due to the deterioration of technological equipment as a result of a low investment. Moreover, only one over twenty-five hospitals experienced an efficient and productive performance, while one over three showed the opposite. The most inefficient and unproductive hospitals are those located in the Central and Caribbean areas (Orozco, 2014).

Figure 1 - Health Expenditure as Percentage

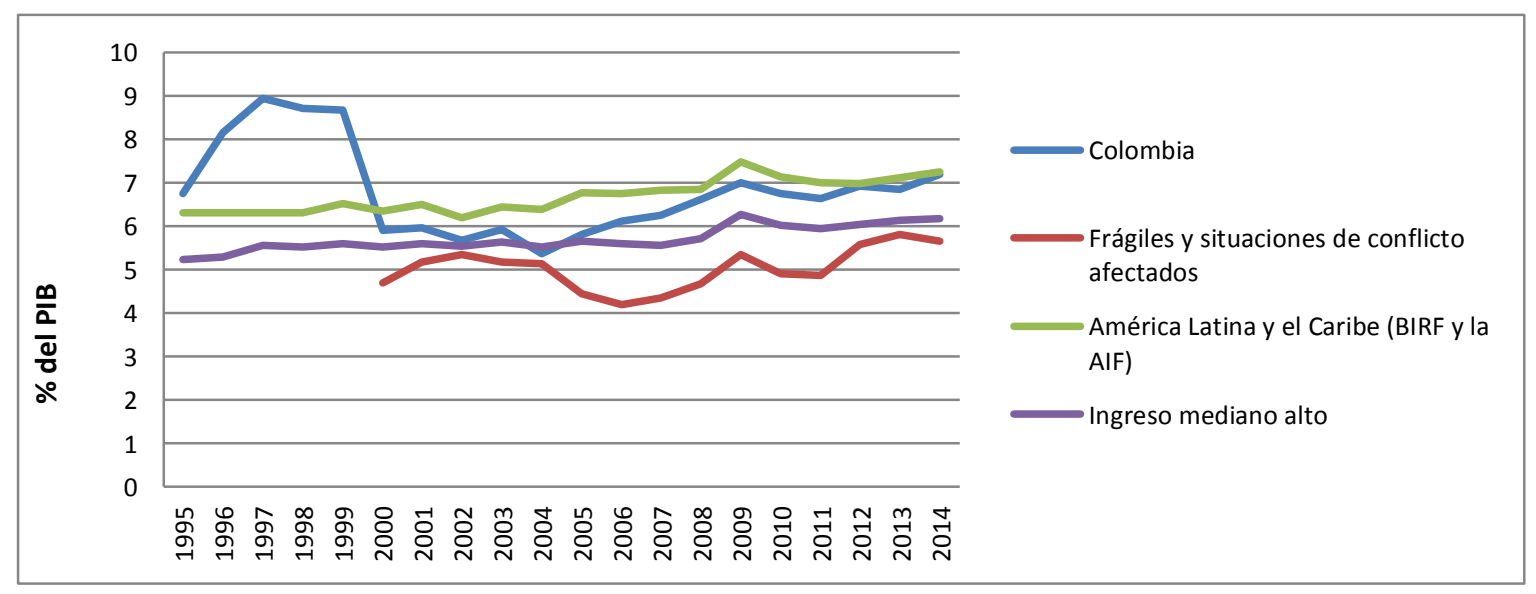

Colombia

Fragile and conflict affected situations.

Latin America and Caribbean (BRIF and AIF)

High Medium Income

Source: (Orozco, 2014).

\footnotetext{
${ }^{4}$ Fedesarrollo, "La sostenibilidad financiera del sistema de salud colombiano -dinámica del gasto y principales retos de cara al futuro" (Financial sustainability of the Colombian Health System-Dynamics of spenditure and main challenges facing the future) Bogotá, 2012.

${ }^{5}$ Ayala Garcia Jhorland, "La salud en Colombia: más cobertura pero menos acceso", en documentos de trabajo sobre economía regional (Health in Colombia: greater coverage but less access, working documents on regional economy, July 2014.
} 
For its part, the Office of the Attorney General of the Republic raises another hypothesis, according to which "... the current events are attributed to the inadequate management of the financial resources of the sector, rather than their scarcity. This is evidenced by publicly known corruption, which is the consequence of an inefficient system of inspection, surveillance and control" (García, 2012).

On May 17, 2015, the Minister of Health spoke out against the risk situation in which 955 public hospitals were in the following terms: "The issue of HPE has become for some public hospitals such as the Cuban blockade for Cuba, that is to say, an external problem with which they justify the clashes and the possible defenses" (El Colombiano, 2015).

There is a widespread perception in the country about the impact of corruption on the functioning of the health system, but there is no conclusive evidence, in terms of statistics and analysis that can scale the problem. There are many headlines, but few systematic studies.

Everything seems to indicate that the most notorious corruption is at the end of the chain, with the providers, in particular the public hospitals or also called State Social Enterprises, which primarily provide the health services for the users of the subsidized regime and the population in the transitory regime.

\section{The optimizing role of social economy enterprises: the mutual organization}

This review of the general system of social security in health in Colombia indicates that there are tensions in a system that constitutionally advocates universality in the provision of the service, but which in practice is far from providing the service in the general interest.

Many signs indicate that this is due to the market orientation of the system, which is based on the perspective of capitalist accumulation and the reproduction of the investment. It generates a classification scheme that depends on the willingness to pay and establishes the link between health promoters, service providers and state social enterprises. Thus, as the general social security system in Colombia has been configured, it has become an alternative capitalist investment, leaving aside the constitutional spirit of social inclusion and welfare. This is one of the reasons why the potential of the social and solidarity economy in this area has been ignored, even though Law 100 of 1993 opens the possibility of providing these services to the population through the forms of legal cooperatives and similar.

Many successful experiences in various countries show that the entities of the social and solidarity economy addressed the provision of service on the basis of the generation of a common good for its members: access to health insurance. Their point of arrival is also measured with the same yardstick: ensuring effective cash or 
the provision of services that are a common good (Álvarez, 2011). This is due to the specificity of the solidarity organizations and in particular of the mutual society.

In the following lines, the relationship between the mutual figure and the health insurance system will be explored as a proposal to reorient the nature of the service provision in Colombia, by optimizing the present system and seeking to achieve its sustainability through the escalation of decision power from local politicians to the communities within a territorial framework. It should also link the elements of general interest that keeps a fundamental service such as health with the necessary adaptation of instruments for the measurement of results in terms of generating a common good.

The history of mutualism, especially on the European continent, identifies it as a social movement embodied in many expressions of social organizations that address services related to social security and social protection. The feeling of mutuality, in all cases, does not occur as a consequence of the development of the organization of mutuality, but this is the basis of its genesis, especially in relation to the formation of satisfactory materials to cover the protection needs (Arboleda \& Zabala, p. 64). In principle, his actions were related to groups excluded from the social security systems (artisans and workers) that found in the formula of mutual association the best instrument to guarantee health services and protection. By evaluating its historical presence, it can easily be determined that it has been a means of overcoming the predominant welfare systems during the first part of the twentieth century or those prior to the formation of welfare states that established such programs after Second postwar period.

Strictly speaking, mutualist action is directly related to the need for human protection. If one considers the thesis of Manfred Max Neef, one can discover that the second fundamental necessity of human beings is protection. According to Arboleda and Zabala (page 67):

\footnotetext{
"Beyond the simple struggle for survival, for access to the elementary minimums to stay alive (air, food and roof), human beings must be guaranteed other medium-term satisfactory that make the former sustainable (health, old age pension, assurances and the like). Social protection, then, is not only a program of government or a slogan for the improvement of working conditions; it is primarily a human need that must be satisfied through nonindividual social instruments and systems. It is up to the State to guarantee them, as most Constitutions say; it is up to the employers to contribute much of them as a means of replenishing the energies of their employees. When neither one nor the other establishes the means and the norms for the population to access the satisfiers of protection, the latter has to look for the indispensable mechanisms to obtain them, which they find in the establishment of self-managed organizations. Thus, mutual associations are an organizational tool of those excluded from social protection to self-generate the satisfactions that are indispensable to them at this level."
}

This is absolutely true according to the historical experience of mutualism in the countries where it has gained greater relevance. However, such an organizational scheme, in Colombia, had not sufficient policies to crowd it among the population, and its normative condition was very scarce.

During the fourth and fifth decades of the twentieth century there was a strong impulse to mutualism in Colombia, understood as organizations that supplied the lack 
of social security system. Formal workers, artisans, and the unemployed in growing cities used these associations as alternatives for satisfying social protection; these organizations included direct health care systems and pension savings mechanisms. Later in the second half of the twentieth century, Colombian mutual societies were strengthened by integration processes and joint actions, but their development was slow and soon they were limited almost exclusively to the provision of funeral services.

At the end of the twentieth century, to a certain extent stimulated by the expectations generated by the promulgation of the general social security law, awareness began to be made about the mutualistic potential, with the understanding that they could intervene in many service areas; Thus, many organizations extended their activities to health care, laboratory services, risk forecasting, savings, credit and education; but specifically limited to the informal working population.

Faced with the crisis of the health and social security system that is now experienced in Colombia, it is absolutely necessary to draw attention to the potential of the mutual organization, so that, through it, more efficient mechanisms can be produced for the management of the savings and for guaranteeing the highest universality of the service. This however implies an agreement on the mechanisms of promotion and some positive norms.

A draft Mutualist Law has been submitted to the Congress of the Republic, considering that these organizations, thanks to their tradition, can contribute to change the institutional instruments for access to social security. This requires releasing mutual associations from certain regulatory obstacles, since many activities that are permitted to mutual societies in other countries, in Colombia are absolutely forbidden. For this reason, a norm in this sense, must start from understanding the potentiality of the mutualist action and the mutualistic association to develop activities that are of their nature and tradition. It also means opening up the recognition of such potential, understanding that the mutual action includes: promotion, foresight, prevention and protection. Concepts that should be understood as "services that are intended to cover various risks that may arise (unforeseeably or surely) or meet present and future needs of partners and their family in relation to their life and quality of life" (Zabala, 2011, p. 151).

The explanatory statement justifying the opening of a legislative debate on Colombian mutualism includes the following central elements:

A) The mutualist rule is oriented by a strictly pragmatic criterion, without taking into account - as fundamental starting point - its nature. That is, the rule is based on the historical presence and the economic tradition of mutualism, as it has been manifested in Colombia, but has not deepened in its essence.

B) Mutualism has not been the subject of specific government policies to promote or preserve it as a tradition. The different laws or administrative acts that have touched 
on this issue have been limited to anticipate the organizational situations and, to a certain extent, to establish control mechanisms, but they have not identified the potentials of this organizational phenomenon to promote community development, to improve quality of life and even to use them in the purpose of state modernization. It has always been left with marginal functions.

C) The rule must start from considering the recent socioeconomic transformations in which the mutual action plays a great importance, especially in relation with protection, foresight and social promotion. Despite the potential of the mutual organization, the legal opportunities for its development are minimal.

In the post-agreement context with the main Colombian guerrilla, the FARC ("Fuerzas Armadas Revolucionarias de Colombia"), it is of prime importance to create mechanisms to offer health coverage to the 15.000 ex-combatants none of which has been in the formal health system. Along with this group it is estimated that over $4,000,000$ Colombians (Historical commission of the conflict and its victims, 2015) who live in the vicinity of the areas of reintegration and training ${ }^{6}$, have no access to health programs.

The aforementioned agreement states that the organization for the economic and social reincorporation is done through an economic, social and solidary organization referred to as Social Economies of the Common (ECOMÚN for their Spanish acronym). The main proposal, which has so far been fulfilled, is for this organization to act as an umbrella for a number of solidary base organizations in the different regions in order to support initiatives of production, transformation, eco-tourism, commercialization, and consumption, as well as other actions that develop economic circuits.

Thus, ECOMÚN progressively concentrates the institutional offer in relation to financial means for shared projects, therefore establishing a basic temporary rent for ex-combatants, access to social security and other actions such as the presence in broadcasting services for reconciliation and peaceful coexistence. In order to fulfill the guarantees of the Agreement carrying out promotion actions and governmental support in relation to ECOMÚN are essential.

From such a stand point the National Solidary Economy Discussion Panel ("la Mesa Nacional de Economía Solidaria"7) currently discusses ways to promote a process that strengthens ECOMÚN as a provider of health in a mutual logic, in partnership of the existing 120 mutual initiatives and with the aim of facilitating the access to the health system of the ex-combatants.

\footnotetext{
${ }^{6}$ Regions where FARC ex-combatants are gathered in order to prepare their reintegration to civil life.

${ }^{7}$ Entity made up by State organisms which promote and supervise solidary and social economy organizations, trades and the academy, represented among others by CIRIEC-Colombia.
} 


\section{Conclusions}

The general system of social security in health was designed as a modern management scheme, that could face competition, with health promotion entities (HPE) being modern and efficient, and health care institutions $(\mathrm{HCl})$ acting in conditions of efficiency and providing the most vulnerable population, without the troubles of profit-driven companies. But they were not prepared to get rid of political influence and corruption. The institutions did not take this aspect into account.

These organizations should be managed far from the interests of politicians, closer to the functioning of organizations of the social and solidarity economy such as mutuals, more depending on the users and their workers. This implies that they should have a more autonomous contracting status, the empowerment of their boards, agile and transparent recruitment processes, and efficient and networked information systems.

Using mutualism, more efficient mechanisms for the management of the expected savings can be produced and can guarantee a greater universality of the service. They could also direct the process of ensuring health coverage for ex-combatants and civilians that have been in regions where historically the Colombian state was not present. However, this implies agreeing on mechanisms for promotion and favorable conditions for its performance, by means of a positive norm.

The optimization of the system is possible if it works more in a logic of common goods than in a logic of public goods, because it frees entities from the ties of professional politicians, who in Colombia use public hospitals as their paying stash, by placing their recommended politicians or by helping their financiers to have contracts to build the health infrastructure and to provide the inputs of health services.

The arguments put forward indicate that:

- It is necessary to emphasize the criteria and instruments for evaluation of public management by the citizens

- The concept of the common good is a good point of departure and of arrival as a strategy of governance in the administration of institutional arrangements that optimize the relations between the public organisms and the citizenship that is expressed through the associations.

The distinctive challenge for the public domain derives from the duality of the public thing: the need to allow citizens, in their plurality, to express their contribution to the life of the community and the need to establish a process of collective choice (Ranson \& Stewart, 1989) that allows the generation of the general interest to express an explanatory relation for the pursuit of the common good (Álvarez, 2011). 


\section{References}

ÁLGARRA, M., Proyecto anticorrupción: implementación de la Nueva Gerencia Pública en Colombia, Instituto de Estudios del Ministerio Público, 2014.

ÁLVAREZ, J., "La noción del bien común como aporte a la nueva gerencia pública colombiana", in Bitácora Gerencial No.1, Instituto de Estudios del Ministerio Público, 2016, V.1, No.1, pp. 72-79.

ÁLVAREZ, J., Innovación y economía social y solidaria: retos y aprendizajes de una gestión diferenciada, I Conferencia Internacional de Economía Solidaria, Barranquilla 2011.

ARBOLEDA, O., ZABALA, H., Mutualismo, exclusión y seguridad social en el valle de Aburrá, Funlam, 2009.

ARGANDOÑA, A., LOSADA, C., TORRALBA, F., Una economía al servicio de la persona, Editorial Milenio, 2015.

BONET, J., GUZMAN, K., "Un análisis regional de la salud en Colombia”, in Documentos de trabajo sobre economía regional, Banco de la República, 2015, No. 222, pp. 1-36.

BRAITHWAITE, J., "Accountability and Governance under the New Regulatory State", in Australian Journal of Public Administration, March 1999, Volume 58, Issue 1, pp. 90-94.

CHANG, H., "Institutions and economic development: Theory, policy, and history", in Journal of Institutional Economics, 2011, Volume 7, Issue 04, pp. 473-498.

COMISIÓN HISTÓRICA DEL CONFLICTO Y SUS VÍCTIMAS, Contribución al entendimiento del conflicto armado en Colombia, Ediciones Desde Abajo, 2015.

CONGRESO DE LA REPÚBLICA DE COLOMBIA, Ley 1751 de 2015, Congreso de la República, 2015.

CONGRESO DE LA REPÚBLICA DE COLOMBIA, Ley 1122 de 2007, Congreso de la República, 2007.

CONGRESO DE LA REPÚBLICA DE COLOMBIA, Ley 100 de 1993, Congreso de la República, 1993.

CORTE CONSTITUCIONAL DE COLOMBIA, Sentencia C053/01, Corte Constitucional de Colombia, 2001.

CORTE CONSTITUCIONAL DE COLOMBIA, Sentencia C-337 de 1993, Corte Constitucional de Colombia, 1993.

CORTE CONSTITUCIONAL DE COLOMBIA, Sentencia C-546 de 1992, Corte Constitucional de Colombia, 1992.

CORTE CONSTITUCIONAL DE COLOMBIA, Sentencia No. T-428/92, Corte Constitucional de Colombia, 1992. 
DAILY PAPER EL COLOMBIANO, Corrupción y clientelismo afectaron a los hospitales públicos. Available at http://m.elcolombiano.com/clientelismo-y-corrupcion-afectan-hospitalespublicos-GH2328239 (consulté le 18 juillet 2016).

ENTHOVEN, A., "The history and principles of managed competition", in Health Affairs, 1993, Volume 13, 24-48.

FELBER, C., The economy of the common good, 6th edition, Ediciones Deusto, 2013.

GARCÍA, M., OROZCO, N., PORT, S., RIVERS, A., Financiamiento del Sistema General de Seguridad Social en Salud Seguimiento y control preventivo a las políticas públicas, Editorial ECOE, 2012.

OROZCO, A., "Una aproximación regional a la eficiencia y productividad de los hospitales públicos colombianos", in Documentos de Trabajo sobre Economía Regional y Urbana, Banco de la República, 2014, No. 201, pp. 1-42.

RANSON, S., STEWART, J., "Citizenship and Government. The Challenge for Management in the Public Domain", in Political Studies, 1989, Volume 37, Issue 1, pp. 5-24.

TORRES-MELO, J., SANTANDER, J., Introducción a las políticas públicas: conceptos y herramientas desde la relación entre Estado y ciudadanía, Ediciones IEMP, 2013.

ZABALA, H., "Tendencias de la legislación sobre la economía solidaria y sus efectos en el mutualismo colombiano", in PÉREZ, J., Reformas legislativas en el Derecho Social y Solidario Iberoamericano, Fundación Divina Pastora, 2011, pp. 139-155. 



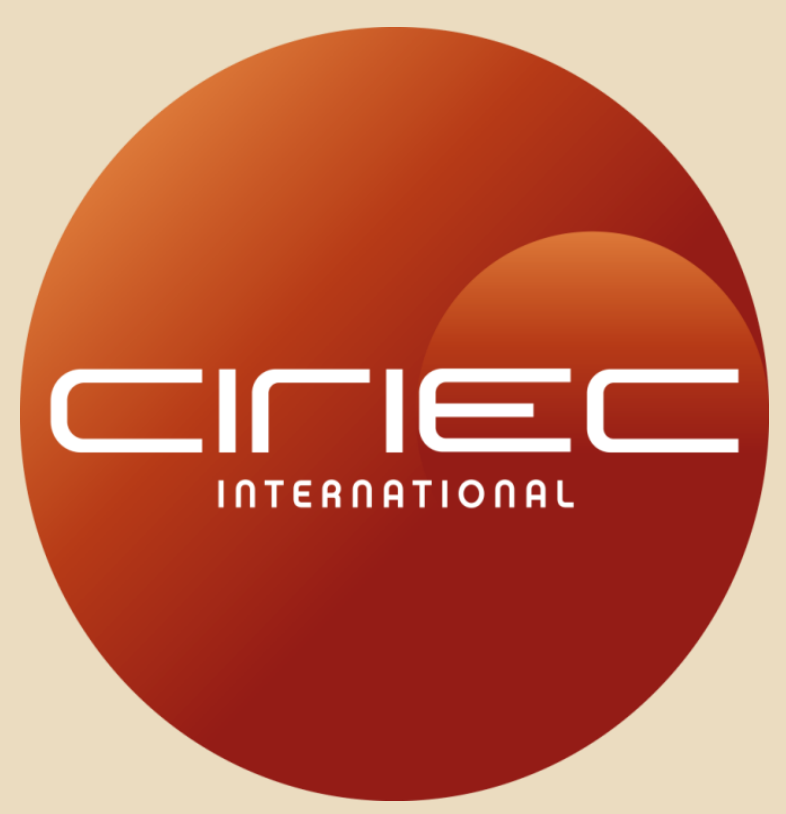

The CIRIEC STUDIES SERIES proposes research results from working groups and commissions of the CIRIEC scientific network in both social and cooperative economy and public economy.

To facilitate accessibility to those research works, this electronic series is proposed in open access, on CIRIEC's website, but also as new series in RePEC.

Each study is available and downloadable as a whole document but also chapter by chapter.

x ciriec@uliege.be

\#ww.ciriec.uliege.be

(https://ideas.repec.org/s/crc/chapte.html 